УДК 378.124.92

(C) Попова О. В., Денисенко А. О., Васильєва С. О., 2021

https://orcid.org/0000-0003-1611-5956

https://orcid.org/0000-0003-4294-7844

https://orcid.org/0000-0001-5012-4835

DOI: $10.34142 / 23128046.2021 .51 .13$

O. B. Попова,

А. О. Денисенко,

С.О. Васильева

\title{
МОНІТОРИНГ ЯКОСТІ ОСВІТИ В СУЧАСНИХ ЗВО
}

У статті доведено актуальність проблеми здійснення моніторингу якості освіти (далі - МЯО) у закладах вищої освіти (далі - 3ВО). Освітній (педагогічний) моніторинг розглянуто в трьох площинах: як процес (циклічний процес порівняння, зіставлення, оцінювання існуючого стану освітнього процесу у $3 В О$ із запланованим його еталоном); як технологію (сукупність певних етапів та відповідних засобів (розробка еталону освітнього процесу, критеріїв та показників очінювання його стану, зіставлення еталонного освітнього процесу з реально існуючим, обтрунтування моделі освітнього прочесу, вивчення перебігу його розвитку, підсумковий контроль його стану та корекиія розробленой моделі); як інформаційну систему, яка постійно оновлюється і поповнюється на основі безперервного відстеження за станом і динамікою розвитку основних складових якості освіти за сукупністю визначених критеріїв із метою вироблення управлінських рішень із коригування небажсаних диспропориій на основі аналізу зібраної інформачії $i$ прогнозування подальшого розвитку досліджуваних прочесів.

Визначено засадничі принципи МЯО у ЗВО (системність і комплексність; студентоцентрованість; оперативність; ефективність; оцінювання для навчання; відкритість; взаємодія і взаємовідповідальність; інтегрованість; перспективність; інноваційність). Сформульовано педагогічні умови забезпечення МЯО у освітньому закладі (створення спеціальних педагогічних умов організаиії МЯО освітнього прочесу ЗВО, які передбачають: підготовку педагогічного колективу до здійснення освітнього моніторингу; забезпечення взаємодії всіх учасників МЯО; розроблення необхідного науково-методичного інструментарію). Запропоновано критеріальну базу МЯО у ЗВО, до якої віднесено комплекс критеріїв (психологічну готовність учасників освітнього процесу до моніторингової діяльності (позитивні мотиви, професійна спрямованість), моніторингову компетентність суб'єктів педагогічного процесу $3 В О$ (спеціальні знання $i$ вміння, особистісні якості), якість моніторингових даних (обсяг інформації, ї̈ валідність та дієвість тощо). 
Презентовано окремі засоби забезпечення МЯО у освітньому заклад («моніторинговий кейс», веб-опитування, тестінг, веб-форуми, вебометричний рейтинг).

Ключові слова: моніторинг, якість освіти, освітній процес, заклад вищої освіти, форми, методи, засоби, інформаційно-комунікаційні технології.

\section{Popova O.V., Denysenko A.O., Vasylieva S. O. Monitoring of quality of} education in modern institutions of higher education. The article proves the urgency of the problem of monitoring the quality of education (hereinafter - MQE) in higher education institutions (hereinafter - HEI). Educational (pedagogical) monitoring is considered in three areas: as a process (cyclical process of comparison, referencing, evaluation of the existing state of educational process in higher educational establishment with its planned standard); as a technology (set of certain stages and appropriate tools (development of the standard of educational process, criteria and indicators for assessing its condition, comparison of the reference educational process with the existing one, substantiation of the educational process model, study of its development, final control of its condition and correction of the developed model ); as an information system that is constantly updated and replenished on the basis of continuous monitoring of the state and dynamics of main components of the quality of education on a set of defined criteria to develop management decisions to correct undesirable imbalances based on analysis of collected information and forecasting further development of research processes. The quality of higher education is considered as a multidimensional concept that covers all aspects of higher educational establishment activity - educational and academic programs, teaching and research work, faculty and students, training base and resources.

The basic principles of MQE in HEI (systemacy and complexity; studentcenteredness, efficiency; effectiveness; assessment for learning; openness; interaction and mutual responsibility; integration; perspective; innovation) are determined. Pedagogical conditions of providing MQE in educational institution are formulated (creation of special pedagogical conditions of MQE organization of educational process of HEI, which provide: preparation of pedagogical collective for educational monitoring; ensuring interaction of all participants of MQE; development of necessary scientific and methodical tools). The criterion base of MQE in HEI is offered, which the complex of criteria (psychological readiness of participants of educational process to monitoring activity (positive motives, professional orientation), monitoring competence of subjects of pedagogical process of HEI (special knowledge and skills, personal qualities), quality of monitoring data (amount of information, its validity and effectiveness, etc.) are related to.

Some means of providing MQE to the educational institution ("monitoring case", web survey, testing, web forums, webometric rating) are presented.

Keywords: monitoring, quality of education, educational process, higher education institution, forms, methods, tools, information and communication technologies. 
Вступ. Нові завдання, які поставлені перед сучасними ЗВО, вимагають якісних змін в управлінні всіма ланками системи освіти, пошуку оптимальних індикаторів ефективності освітнього процесу. Наразі утворилась необхідність розроблення й упровадження відповідної соціальному замовленню системи вивчення, аналізу й педагогічного прогнозування, яка даватиме можливість отримувати об'єктивну інформацію про перебіг освітнього процесу. Цю проблему в змозі розв'язати моніторинг, суть якого полягає в синхронізації процесів спостереження, замірювання, отримання на такій основі нових знань про стан об'єкта 3 подальшим моделюванням, прогнозуванням та прийняттям відповідного управлінського рішення. Від якості організації моніторингу значною мірою залежить удосконалення освітнього процесу ЗВО, якому були б властиві гнучкість, демократизм, мобільність, здатність до самоорганізації.

Однією з головних причин актуалізації проблеми ефективного та успішного моніторингу якості освіти є розуміння того, що сьогодні в нашій країні утворилися досить суттєві суперечності між необхідністю оновлення змісту, організації освітнього процесу у ЗВО та недостатнім рівнем обгрунтованості управлінських рішень щодо вирішення означених завдань. Уважаємо, що наявність зазначених суперечностей значною мірою зумовлена низьким рівнем науково-інформаційного забезпечення процесу управління, що не дає можливості правильного прогнозування перебігу та провідних тенденцій розвитку освітньої системи країни в цілому i окремими закладами освіти зокрема, розроблення науково обгрунтованих рекомендації щодо прийняття оптимальних управлінських рішень із метою підвищення результативності діяльності ЗВО.

Наразі дослідженню проблеми моніторингу присвячено праці багатьох зарубіжних і вітчизняних учених. Теоретико-методологічні засади моніторингу розглядаються в працях І. Бестужева-Лади, Т. Заславської, О. Касьянової, О. Майорова, Н. Пішулина, А. Савельєва, А. Субетто, Р. Шишова та ін.

Суть, закономірності, особливості організації педагогічного моніторингу, різні аспекти забезпечення його здійснення досліджуються в наукових працях В. Беспалька, Б. Бітінас, Е. Зеєра, В. Зубко, В. Кальней, А. Майорова, I. Підласого, Г. Цехмістрової, В. Циби, та інших учених. Г. Сльнікова, О. Мармаза, А. Орлов, Є. Хриков розглядають моніторинг у контексті підвищення якості управлінських рішень та впровадження інновацій у галузі освіти. Дослідження Т. Волобуєвої, Л. Генденштейна, О. Касьянової, Т. Лукіної, А. Майорова, П. Семиволос, А. Сєврук, 3. Рябової, Е. Юніної присвячені моніторингу якості освіти в 33СО; надбання М. Загірняка - аналізу науковопрактичних засад моніторингу в освіті, а також деяким питанням моніторингу як форми пізнавальної діяльності; праці А. Дахіна - моніторингу успішності та ефективності навчальної роботи. 
Мета та завдання. Розкрити теоретичні засади моніторингу якості освіти в сучасних ЗВО та презентувати окремі сучасні форми і методи його здійснення.

Методи дослідження. Під час наукового пошуку розв'язання порушеної проблеми використовували комплекс методів науково-педагогічного дослідження: теоретичних (вивчення філософської, педагогічної, психологічної, методичної літератури 3 метою критичного аналізу з позицій сьогодення наукових ідей і поглядів учених щодо порушеної проблеми; проєктування i моделювання, аналіз педагогічного досвіду, причинно-наслідковий аналіз отриманих емпіричних даних; емпіричних (дослідно-експериментальна робота, спостереження, анкетування, тестування, бесіда, самооцінювання студентів, експертна оцінка).

Результати. Аналіз наукових праць дає підстави свідчити, що моніторинг зазвичай визначається науковцями як: 1) метод дослідження реальності, який застосовується в різних галузях науки і практики; 2) метод забезпечення сфери управління різноманітними видами освітньої діяльності шляхом надання своєчасної й об'єктивної інформації (Annenkova, n. d.).

У процесі дослідження дійшли висновку, що освітній (педагогічний) моніторинг доцільно розглядати в трьох площинах: як процес, як систему, як технологію (Denisenko, 2008):

- як процес моніторинг розглядаємо як циклічний процес порівняння, зіставлення, оцінювання існуючого стану освітнього процесу у ЗВО із запланованим його еталоном (стандартом, бажаною моделлю) та прийняття на цій основі управлінського рішення щодо поточного коригування структури освітнього середовища чи процесів, які відбуваються в освітньому закладі;

- як систему моніторинг визначаємо як інформаційну систему, яка постійно поповнюється завдяки ретельному відстеженню перебігу освітнього процесу у ЗВО як об'єкта управління за визначеними критеріями, що включає обов'язковий поточний контроль, оцінку, корекцію стану досліджуваного об’єкта (у нашому випадку - освітнього процесу у ЗВО) для оперативного прийняття правильного управлінського рішення щодо прогнозування напрямів подальшого розвитку означеного процесу 3 урахуванням рефлексивного ставлення до цього всіх його учасників;

- як технологію моніторинг являє собою сукупність певних етапів та відповідних засобів (розробка еталону освітнього процесу, критеріїв та показників оцінювання його стану, зіставлення еталонного освітнього процесу 3 реально існуючим, обгрунтування моделі освітнього процесу, вивчення перебігу його розвитку, підсумковий контроль його стану та корекція розробленої моделі). 
Під моніторингом в освіті в широкому сенсі розуміємо систему збирання, обробки, зберігання й розповсюдження інформації про педагогічну (освітню) систему або окремі їі компоненти, яка орієнтована на інформаційне забезпечення управління, що дає можливість дійти висновків про стан досліджуваного об'єкта у будь-який момент часу і дає прогноз іiї розвитку (Annenkova, n. d.; Harkivska, n. d.).

Здійснення феноменологічного аналізу моніторингу в освітньому закладі потребує визначення поняття «якість освіти».

У прийнятій в листопаді 1998 р. на Міжнародній конференції Всесвітній декларації з вищої освіти вказано, що якість означеної освіти є багатовимірним феноменом, який має охоплювати всі види й аспекти діяльності 3ВО: професорсько-викладацький склад і склад здобувачів освіти, навчальні та робочі програми, навчально-пізнавальну і навчально-дослідницьку роботу, навчальну базу, ресурсні можливості тощо (Lyashenko, 2005).

У широкому розумінні якість освіти розглядають як збалансовану відповідність організації освітнього процесу, його результату і всієї освітньої системи меті, потребам, соціальному замовленню і стандартам освіти; у вузькому - як перелік вимог до особистості, освітнього середовища й системи освіти, що реалізує їх на певних етапах навчання здобувача освіти, якому відповідає визначена сукупність показників (Lyashenko, 2005).

Моніторинг якості освіти (далі - МЯО) у $3 В О$ розглядаємо як інформаційну систему, яка постійно оновлюється і поповнюється на основі безперервного відстеження за станом і змінами у розвитку основних компонентів освітнього процесу за комплексом визначених критеріїв для вироблення управлінських рішень із коригування небажаних невідповідностей $\mathrm{i}$ диспропорцій на основі аналізу зібраної інформації і прогнозування подальшого розвитку досліджуваних об'єктів (Annenkova, n. d.; Denisenko, 2008).

За внутрішньою структурою МЯО у ЗВО акумулює в собі такі важливі складники, як: аналіз, оцінку й прогнозування освітнього процесу; сукупність методів і прийомів відстеження змін у всіх ланках і параметрах освітнього середовища 3ВО; збирання i обробку інформації 3 метою розроблення рекомендацій щодо вдосконалення освітнього процесу та професійної підготовки здобувачів вищої освіти і внесення необхідних коректив для оптимізації вказаних процесів (Annenkova, n. d.).

Провідними завданнями МЯО у ЗВО вважаємо такі: 1) розроблення комплексу критеріїв та показників, які в змозі забезпечити цілісну картину щодо стану освітнього процесу у ЗВО, якісних й кількісних змін у вказаному процесі; 2) збирання і систематизація інформації про стан і розвиток освітнього процесу у ЗВО; 3) забезпечення регулярного й транспарентного надання інформації про 
процеси, які відбуваються в освітньому середовищі 3ВО; 4) на основі аналізу отриманої інформації щодо стану освітнього процесу здійснення прогнозування його розвитку, вироблення управлінських рішень.

Необхідно підкреслити, що одним із важливих завдань моніторингу є також попередження чинників, які негативно впливають на об'єкта. При цьому це означає не просто констатація факту утворення негативних чинників, а запровадження превентивних корегувальних заходів у освітньому процесі для зміни ситуації. У такий спосіб утворюється можливість запобігти або мінімізувати можливий деструктивний розвиток освітнього процесу.

Засадничими принцииами МЯО у ЗВО вважаємо такі:

1. Системність $i$ комплексність: оцінку діяльності викладача ЗВО доцільно розглядати не тільки з позиції навчальних досягнень здобувачів вищої освіти, а й у соціально-економічному контексті; відпрацювати систему критеріїв (індикаторів) якості освіти, яка в змозі надати можливість ураховувати зміни в усіх елементах досліджуваного об’єкта. При цьому доцільно звернутися до світового досвіду створення ефективних систем критеріїв (індикаторів) якості освіти (у тому числі систему індикаторів якості освіти Свропейського Союзу). Реалізація означеного принципу дає можливість здійснювати більш об'єктивний й різнобічний аналіз рівня навчальних досягнень майбутніх фахівців.

2. Студентоцентрованість: передбачає в процесі МЯО акцентування на навчанні та розвитку особистості кожного здобувача освіти; оцінювання сукупності умов для отримання персоніфікованої освіти кожним студентом, які забезпечують повною мірою розкриття в майбутніх фахівців внутрішніх ресурсів та творчого потенціалу.

3. Оперативність: результати моніторингового дослідження мають стимулювати заходи щодо удосконалення освітнього процесу.

4. Ефективність: у процесі здійснення моніторингу слід показувати не тільки узагальнені результати, а висвітлювати індивідуальні прогресивні зміни в кожного здобувача освіти, тобто основою визначення ефективності діяльності викладача, академічної групи $3 \mathrm{BO}$ за визначений період $\epsilon$ особистіснопрофесійне зростання кожного здобувача освіти на тлі всіх студентів освітнього закладу, які мають із ним однаковий рівень навчальних досягнень на початку досліджуваного періоду й аналогічні соціально-економічні й організаційнопедагогічні умови навчання за означений період.

5. Очінювання для навчання (на противагу оцінювання навчання): система критеріїв (індикаторів) МЯО у ЗВО має бути інструментом удосконалення освітнього процесу (не тільки констатувати стан досліджуваного об'єкта на момент завершення моніторингового дослідження, а й відбивати динаміку параметрів освітнього процесу в цілому і кожного здобувача освіти 
зокрема, що дає можливість здійснювати всебічне діагностування та прогностику); моніторингове дослідження навчальних досягнень студентів має відбивати сучасні тенденції поширення компетентнісної парадигми вищої освіти.

6. Вiдкритість: дотримання транспарентного підходу (ураховувати інформаційні потреби всіх учасників освітнього процесу - здобувачів освіти, керівників структурних підрозділів 3ВО, батьків, громадськості.

7. Взаємодія $і$ взаємовідповідальність: для здійснення об'єктивного МОЯ необхідно залучати до його організації і проведення всі підрозділи ЗВО викладачів, здобувачів освіти, додаткових спостерігачів (громадські організації, експертів та ін.), адже тільки в колективній діяльності, заснованій на співпраці та співдружності, можна оптимально досягти поставлених цілей, подолати певні труднощі тощо.

8. Інтегрованість: МЯО передбачає зміцнення зв'язків між контролем, самооцінкою і вдосконаленням освітнього процесу; основу для розроблення перспективних планів удосконалення роботи ЗВО і контролю за їх виконанням мають складати результати внутрішнього самомоніторингу ЗВО та результати зовнішнього оцінювання в рамках національної системи МЯО.

9. Перспективність: МЯО у ЗВО має бути орієнтована на перспективні, довгострокові, масштабні цілі, які можуть привести до дійсно докорінних змін якості освітнього процесу.

10. Інноваційність: здійснення МЯО вимагає дотримання нових методологічних підходів; максимального використання можливостей IКТ для забезпечення ефективності МЯО (Lyashenko, 2005; Moroz, Romanovskiy, Moroz, Gren, Pomaza-Ponomarenko \& Popova, 2021; Harkivska, n. d.).

У процесі експериментального дослідження нами визначено педагогічні умови організації МЯО освітнього процесу ЗВО, які передбачають: підготовку педагогічного колективу до здійснення освітнього моніторингу; забезпечення взаємодії всіх учасників МЯО; розроблення необхідного науково-методичного інструментарію.

Робота із забезпечення моніторингу науково-методичним інструментарієм має поєднувати соціологічні, психологічні та педагогічні методики 3 метою отримання об'єктивних даних щодо якості освіти у ЗВО. Для учасників моніторингового дослідження бажано створити базовий діагностичний набір, який має містити зразки анкет (для студентів, аспірантів, викладачів, батьків, управлінців), інструкції для опрацювання результатів, тести рівня розвитку особистісних якостей суб'єктів освітнього процесу, діагностик біопсихічних i професійних якостей здобувачів освіти для дослідження мотивації; експертні карти, креативні завдання, пакет ситуативних завдань для діагностики рівня 
сформованості ключових компетентностей, узагальнювальні картки, які відображають рівень вихованості студентів, таблиці узагальнення даних тощо (Denysenko, 2008).

Як свідчать результати нашого експериментального дослідження, науковометодичний та управлінський супровід педагогічного моніторингу доцільно оформити як «моніторингові кейси», до яких входять: методичні посібники, нормативні документи; дискети з завданнями, бланками, таблицями; збірки тренінгових і контрольних завдань; відеокасети уроків педагогів-майстрів 3 елементами моніторингових досліджень; коментарі методистів, психологів, науковців.

За останні роки в системі вищої освіти України проведена значна робота 3 інформатизації освітнього середовища у ЗВО, що створює передумови для якісно нового етапу впровадження IКТ у освіту взагалі, та забезпечення моніторингових досліджень зокрема: накопичено досить значний практичний досвід створення i використання у ЗВО інформаційних технологій дидактичного призначення різного рівня - від автоматизованих систем управління (АСУ), інформаційноаналітичних систем управління (IАCУ) діяльністю ЗВО до багатофункціональних комплексів Internet i освітньо-наукових порталів (Bodnenko, Zhiltsov, Leschinskiy \& Mazur, 2014).

Моніторинг освітнього процесу у ЗВО має враховувати специфічні параметри державних і суспільних цінностей, що, у свою чергу, вимагає безпосередню участь усіх зацікавлених представників громадськості в управлінні освітніми закладами.

На думку науковців (Д. Бодненко, О. Жильцов, О. Лещинський, Н. Мазур та ін.), в основі такої моделі, як управління, лежить використання сучасних IКТ і широке застосування можливостей комп'ютерних мереж (Bodnenko, Zhiltsov, Leschinskiy \& Mazur, 2014).

Наразі мережа Internet дає можливість використовувати інструменти, які дозволяють отримувати, реєструвати, обробляти дані, одержані від користувачів. До таких інструментів належать веб-опитування, тестінг, веб-форуми, вебометричний рейтинг тощо. Розміщені на веб-сайтах означені інструменти дають можливість забезпечити врахування думки кожного зацікавленого користувача.

Реалізація сучасних моделей моніторингу в управлінні ЗВО заснована на створенні в ньому цілеспрямованого інформаційного середовищза (далі - IC).

Під IC моніторингу освітнього процесу у ЗВО розуміють сукупність суб'єктів моніторингу (абітурієнтів, здобувачів освіти, викладачів, адміністрації освітнього закладу), технічних і програмних засобів зберігання, передачі та обробки інформації, що забезпечують постійне автоматизоване нагромадження 
знань про динаміку результативності освітнього процесу, а також особистісні зміни в його учасників.

Основна мета IC - залучення зацікавлених користувачів до безпосередньої участі в життєдіяльності 3ВО через прямий, рівноправний і постійний обмін інформацією.

Завданнями IC є забезпечення:

- постійного каналу передачі структурованої інформації від учасників освітнього процесу в інформаційну систему 3ВО;

- обробки отриманої інформації;

- зберігання отриманої інформації;

- надання отриманої інформації респондентам і керівництву 3ВО;

- обговорення обробленої інформації респондентами, інформації середовища з керівництвом вузу;

- спільного прийняття управлінських рішень.

Основна відмінність IC моніторингу освіти від наявних у кожному 3ВО веб-сайтів полягає в забезпеченні каналу передачі інформації від зацікавлених груп користувачів (абітурієнтів, здобувачів вищої освіти, педагогів) в середовище.

3 точки зору інструментарію відмінність інформаційного середовища моніторингу від веб-сайту полягає в широкому використанні засобів, що дозволяють передавати інформацію від користувачів в середовище i між користувачами.

Серед інструментів для врахування думки учасників МЯО добре зарекомендували себе в мережі Internet: форуми; опитування; тестування; сховища даних IC; вебометричні сайти тощо.

Використання сучасних IKT у МЯО забезпечує синергетичний та транспарентний ефект унаслідок залучення в моніторингові дослідження широких мас громадськості, що приводить до прискорення процесу модернізації освітнього процесу в результаті підвищення інформованості органів управління ЗВО щодо безупинно мінливих потреб. Залучення за допомогою IC y моніторингові дослідження представників «довузівської» (абітурієнтів, батьків, учителів) i «післявузівської» (випускників, слухачів центру підвищення кваліфікації, керівників підприємств, працівників служби зайнятості тощо) громади може вплинути на всі ланки системи освіти (середню загальну, початкову, професійну, вищу, післядипломну освіту).

Основними критеріями і показниками, що характеризують організацію МЯО у ЗВО, було визначено: психологічну готовність учасників освітнього процесу до моніторингової діяльності (позитивні мотиви, професійна спрямованість), моніторингову компетентність суб'єктів педагогічного процесу 
ЗВО (спеціальні знання і вміння, особистісні якості), якість моніторингових даних (обсяг інформації, ï валідність та дієвість тощо). Для оцінки впливу забезпечення визначених умов організації моніторингу на ефективність освітнього процесу ЗВО доцільно використовувати інтегрований критерій якості, який складають: упорядкованість освітнього процесу, єдність педагогічного колективу, результативність професійної підготовки майбутніх фахівців, сприятливе освітнє середовище освітнього закладу.

Обговорення. Аналіз дисертаційних досліджень і наукових публікацій (Д. Бодненко, І. Герасимов, О. Жильцов, Т. Заславська, О. Лещинський, Н. Мазур, О. Майоров, С. Хриков, Р. Шишов та ін.) свідчить про підвищення інтересу науковців до проблеми МЯО. Проте, аналіз досліджень моніторингу в галузі освіти дає підстави констатувати, що в означеній сфері ще існує ціла низка невирішених проблем як теоретичного, так і прикладного характеру. Зокрема, наразі не існує спільної думки 3 такого ключового питання, як визначення поняття «моніторинг», методологічні засади його використання в сучасних закладах освіти, педагогічне забезпечення моніторингових досліджень тощо. Отримані нами результати науково-дослідної роботи в цілому збігаються із здобутками інших дослідників.

Воднораз, порівняно з попередніми працями, у статті представлено авторський підхід до визначення методологічних підходів до освітнього моніторингу і вимог до його використання в практиці ЗВО, подальшого розвитку набули форми і методи забезпечення педагогічних умов його здійснення. Уважаємо, що в подальшому науковцям слід більше уваги приділити пошуку оптимальних форм, методів, технологій внутрішнього МЯО у ЗВО, підготовці професорсько-викладацького складу та майбутніх фахівців освітньої сфери до проведення моніторингових досліджень, що має стати перспективними напрямами подальших наукових розвідок у означеному напрямі.

Висновки. Спрямування ЗВО на досягнення якісно нових освітніх результатів зумовлює потребу переходу від традиційного способу внутрішнього контролю до управління освітнім процесом, інформаційною основою якого $є$ МЯО. Освітній моніторинг являє собою достатньо складний й неоднозначний феномен. Він застосовується у різних сферах освітньої галузі і з різноманітними цілями, але при цьому має загальні ознаки, характеристики і властивості.

Освітній моніторинг є цілісним управлінським інструментом, який дає можливість збирати, обробляти, зберігати, поширювати інформацію про діяльність освітніх систем, визначати ї стан і прогнозувати подальший розвиток. МЯО у ЗВО спрямований на отримання оперативної, об'єктивної та достовірної інформації про якість освітніх результатів, умов і витрачених ресурсів їх досягнення. Системний моніторинг в змозі сформувати надійне 
інформаційне поле, аналіз даних якого дозволить відстежувати реальну ситуацію в діяльності ЗВО, прогнозувати іiі розвиток, приймати оперативні управлінські рішення щодо корегування визначених стратегій забезпечення якості освітнього процесу.

Засадничими принципами МЯО у ЗВО визначено такі: системність і комплексність; студентоцентрованість; оперативність; ефективність: оцінювання для навчання; відкритість; взаємодія і взаємовідповідальність; інтегрованість; перспективність; інноваційність. Забезпечення МЯО у освітньому закладі вимагає: 1) створення спеціальних педагогічних умов організації МЯО освітнього процесу ЗВО, які передбачають: підготовку педагогічного колективу до здійснення освітнього моніторингу; забезпечення взаємодії всіх учасників МЯО; розроблення необхідного науково-методичного інструментарію; 2) визначення критеріальної бази МЯО у ЗВО, до якої віднесено комплекс критеріїв (психологічну готовність учасників освітнього процесу до моніторингової діяльності (позитивні мотиви, професійна спрямованість), моніторингову компетентність суб'єктів педагогічного процесу ЗВО (спеціальні знання і вміння, особистісні якості), якість моніторингових даних (обсяг інформації, ії валідність та дієвість тощо).

\section{ЛITEPATУPA:}

Аннєнкова I. П. Моніторинг якості освіти у BH3. URL : http://e-learning.onu.edu.ua

Бодненко Д. М., Жильцов О. Б., Лещинський О. Л., Мазур Н. П. Моніторинг навчальної діяльності: навч. посібник. К: Київський університет імені Бориса Грінченка, 2014. $276 \mathrm{c}$.

Денисенко А. О. Організація моніторингу виховної системи вищих педагогічних навчальних закладів : автореф. дис. ... канд. пед. наук : 13.00.01 «Загальна педагогіка та історія педагогіки». Харків, 2008. 20 с.

Ляшенко О. І. Якість освіти як основа функціонування й розвитку сучасних систем освіти. Педагогіка і психологія. 2005. № 1. С. 5-12.

Моніторинг якості освіти. URL : http://timo.com.ua/node/7213

Мороз С. А., Романовський О. Г., Мороз В.М., Грень Л. М., Помаза-Пономаренко А. Л., Попова О. В. Залежність якості вищої освіти від джерел їі фінансування та спеціалізації 3ВО: аналіз думки роботодавців і напрями вдосконалення державної політики. Фінансово-кредитна діяльність: проблеми теорії $i$ практики. Том 2. № 37 (2021). URL : https://fkd.ubs.edu.ua/index.php/fkd/article/view/3176

Харківська А. Сутність педагогічного моніторингу якості виховного процесу у вищих педагогічних навчальних закладах. http://repository.khpa.edu.ua:8080/jspui/bitstream/123456789/2569/1/4F4C 1.PDF

Хриков Є. М. Теоретико-методологічні засади моніторингу професійної підготовки. URL : http://www.profosvita.org.ua/ru/career/articles/2.html

Хриков С. М. Управління навчальним закладом. К. : Знання, 2006. 365 с.

\section{REFERENCES:}

Annenkova, I. P. (n. d.). Monitorynh yakosti osvity u VNZ. [Monitoring the Quality of Education in Universities]. URL : http://e-learning.onu.edu.ua (in Ukrainian). 
Bodnenko, D. M., Zhiltsov, O. B., Leschinskiy, O. L. \& Mazur, N. P. (2014). Monitorynh navchalnoi diialnosti: navch. posibnyk. [Monitoring of Educational Activity: Textbook. manual] K : Kyivskyi universytet imeni Borysa Hrinchenka. 276 s. (in Ukrainian).

Denysenko, A. O. (2008). Orhanizatsiia monitorynhu vykhovnoi systeme vyshchykh pedahohichnykh navchalnykh zakladiv [Organization of Monitoring of the Educational System of Higher Pedagogical Educational Institutions]: avtoref. dys. ... kand. ped. nauk : 13.00.01 «Zahalna pedahohika ta istoriia pedahohiky». Kharkiv. 20 s. (in Ukrainian).

Lyashenko, O. I. (2005). Yakist osvity yak osnova funktsionuvannia i rozvytku suchasnykh system osvity [Quality of Education as a Basis for the Functioning and Development of Modern Education Systems]. Pedahohika i psykholohiia. 2005. \# 1. S. 5-12. (in Ukrainian).

Monitorynh yakosti osvity (n. d.). [Monitoring the Quality of Education]. URL : http://timo.com.ua/node/7213 (in Ukrainian).

Moroz, S. A., Romanovskiy, O. G., Moroz, V. M., Gren, L. M., Pomaza-Ponomarenko, A. L. \& Popova, O. V. (2021). Zalezhnist yakosti vyshchoi osvity vid dzherel yii finansuvannia ta spetsializatsii ZVO: analiz dumky robotodavtsiv i napriamy vdoskonalennia derzhavnoi polityky [Dependence of the Quality of Higher Education on the Sources of its Financing and Specialization of Free Economic Education: Analysis of the Opinion of Employers and Directions of Improvement of the State Policy]. Finansovo-kredytna diialnist: problem teorii i praktyky.

Tom 2. \# 37. URL:https://fkd.ubs.edu.ua/index.php/fkd/article/view/3176 (in Ukrainian).

Harkivska, A. (n. d.). Sutnist pedahohichnoho monitorinhu yakosti vihovnoho protsesu u vyshchih pedahohichnykh navchalnykh zakladakh [The Essence of Pedagogical Monitoring of the Quality of the Educational Process in Higher Pedagogical Educational Institutions]. URL : http://repository.khpa.edu.ua:8080/jspui/bitstr eam/123456789/2569/1/4F4C 1.PDF

Hrykov, E. M. (n. d.). Teoretyko-metodolohichni zasady monitorynhu profesiinoi pidhotovky [Theoretical and Methodological Principles of Training Monitoring]. URL: http://www.profosvita.org.ua/ru/career/articles/2.html (in Ukrainian)

Hrykov, E. M. (2006). Upravlinnia navchalnym zakladom [Educational Institution Management]. K. : Znannia. 365 s. (in Ukrainian).

\section{Інформація про авторів:}

\section{Попова Олена Володимирівна}

ORCID: http://orcid.org/0000-0003-1611-5956 Попова О.В.; доктор педагогічних наук, професор, професор кафедри освітології та інноваційної педагогіки, Харківський національний педагогічний університет імені Г. С. Сковороди, вул. Алчевських, 29, Харків, Україна, 61002

e-mail: tubayeva07@gmail.com

\section{Денисенко Анжела Олегівна}

ORCID: https://orcid.org/0000-0003-4294-

7844 Денисенко А. О.; кандидат педагогічних наук, доцент, доцент кафедри освітології та інноваційної педагогіки, Н. S. Skovoroda Kharkiv National Pedagogical University, Kharkiv, Alchevskykh Street, 29,

\section{Information about the authors: Popova Olena Volodymyrivna:}

ORCID: http://orcid.org/0000-0003-1611-5956 Popova O.V.; Doctor of Pedagogical Sciences, Professor, Professor of the Department of Education and Innovative Pedagogy, H.S. Skovoroda Kharkiv National Pedagogical University, Kharkiv, Alchevskykh Street, 29, Kharkiv, Ukraine, 61002

e-mail: tubayeva07@gmail.com

\section{Denysenko Anzhela Olehivna:}

ORCID: https://orcid.org/0000-0003-42947844 Denysenko A. O.; PhD, Associate Professor, Associate Professor of the Department of Education and Innovative Pedagogy, H. S. Skovoroda Kharkiv National Pedagogical University, Alchevskykh Street, 29, Kharkiv, Ukraine, 61002 
Kharkiv, Ukraine, Kharkiv, Alchevskykh

Street, 29, Kharkiv, Ukraine, 61002

e-mail: angelps1505@gmail.com

e-mail: angelps1505@gmail.com

\section{Васильсва Світлана Олександрівна}

ORCID: http://orcid.org/0000-0001-5012-4835

Васильєва C.О.; доктор педагогічних наук, доцент, професор кафедри освітології та інноваційної педагогіки, Харківський національний педагогічний університет імені Г. С. Сковороди, вул. Алчевських, 29, Харків, Україна, 61002

\section{Vasylieva Svitlana Olexandrivna:}

ORCID:http://orcid.org/0000-0001-5012-4835

Vasylieva S.O. Doctor of Pedagogical

Sciences, Associate Professor, Professorof the

Department of Education and Innovative

Pedagogy, H.S. Skovoroda Kharkiv National

Pedagogical University, Kharkiv, Alchevskykh

Street, 29, Kharkiv, Ukraine, 61002

e-mail: svitlana.vasileva@hnpu.edu.ua

e-mail: svitlana.vasileva@hnpu.edu.ua

Цитуйте цю статтю як: Попова О. В., Денисенко А. О., Васильєва С. О. Моніторинг якості освіти в сучасних ЗВО. Теорія та методика навчання та виховання. 2021. № 51. С. 133-145. DOI: $10.34142 / 23128046.2021 .51 .13$

Дата надходження статті до редакції: 1.10.2021

Стаття прийнята до друку: 15.10.2021 